\author{
UNIVERSIDADE DE SÃO PAULO \\ FACULDADE DE ECONOMIA, ADMINISTRAÇÃO E \\ CONTABILIDADE \\ DEPARTAMENTO DE ECONOMIA \\ PROGRAMA DE PÓS-GRADUAÇÃO EM ECONOMIA
}

\title{
Education quality and non-covergence
}

Qualidade da educação e não-convergência

\author{
Danilo Paula de Souza
}

Orientador: Prof. Dr. Mauro Rodrigues Júnior

São Paulo - Brasil

2015 

Prof. Dr. Marco Antonio Zago

Reitor da Universidade de São Paulo

Prof. Dr. Adalberto Américo Fischmann

Diretor da Faculdade de Economia, Administração e Contabilidade

Prof. Dr. Hélio Nogueira da Cruz

Chefe do Departamento de Economia

Prof. Dr. Márcio Issao Nakane

Coordenador do Programa de Pós-Graduação em Economia 



\title{
DANILO PAULA DE SOUZA
}

\section{Education quality and non-covergence \\ Qualidade da educação e não-convergência}

\author{
Dissertação apresentada ao Depar- \\ tamento de Economia da Faculdade \\ de Economia, Administração e Con- \\ tabilidade da Universidade de São \\ Paulo como requisito parcial para a ob- \\ tenção do título de Mestre em Ciências.
}

Orientador: Prof. Dr. Mauro Rodrigues Júnior

\section{Versão Corrigida}

(versão original disponível na Faculdade de Economia, Administração e Contabilidade)

São Paulo - Brasil

2015 


\section{FICHA CATALOGRÁFICA}

Elaborada pela Seção de Processamento Técnico do SBD/FEA/USP

\section{Souza, Danilo Paula de}

Education quality and non-converge / Danilo Paula de Souza. -- São Paulo, 2015.

$65 \mathrm{p}$.

Dissertação (Mestrado) - Universidade de São Paulo, 2015.

Orientador: Mauro Rodrigues Júnior.

1. Capital humano 2. Crescimento econômico 3. Não-convergência 4. Escolha ocupacional I. Universidade de São Paulo. Faculdade de Economia, Administração e Contabilidade. II. Título.

$$
\text { CDD }-657.4
$$


A todos aqueles que insistem em se perguntar o porquê do porquê das coisas. 



\section{Agradecimentos}

A toda minha família, que sempre me ofereceu suporte durante todos esses anos, mesmo quando a resolução de listas adentrava a madrugada. A minha mãe em especial, pela companhia diária e pelo apoio incondicional, apesar de não concordar com grande parte das minhas decisões nesse período.

Aos meus amigos de colégio, que me ajudaram incontáveis vezes com as intuições por trás dos resultados preliminares da dissertação, e que sempre estiveram presentes nos (importantes) momentos em que o mestrado não era a pauta. Agradecimento também aos amigos que não do colégio, mas que a vida se encaminhou de me apresentar ao longo desses últimos anos e que foram também muito importantes durante todo esse período.

Aos meus amigos Nelson, Letícia e Jordana pelas discussões mais profundas e por vibrarem comigo a cada conquista. A minha amiga Chrissie pela imensa ajuda na fase final do trabalho, em especial ao esforço de revisão da escrita.

Aos colegas de graduação e mestrado Raí, Bruno e Antonio, que me acompanharam na rotina cansativa da faculdade e que contribuíram imensamente com o desenvolvimento do tema e idéias propostas nesse trabalho.

Ao meu orientador, Prof. Mauro Rodrigues Jr., por todo o trabalho de orientação, não apenas nessa dissertação, mas também na vida acadêmica de maneira geral. Com ele aprendi a ser um interessado por economia antes de tudo. 

" I am indebted to my father for living, but to my teacher for living well." Alexandre, o Grande

" The direction in which education starts a man will determine his future life." 



\section{Resumo}

Esta dissertação analisa o papel da qualidade da educação no processo de convergência do PIB per capita através do impacto da qualidade de professores na formação de capital humano. O modelo de gerações sobrepostas proposto sugere que o nível inicial de capital humano dos professores é importante para explicar o fenômeno da não-convergência, mesmo quando o retorno marginal da qualidade da educação é decrescente. Esta não-convergência surge porque um baixo nível inicial de capital humano dos professores se traduz em um baixo nível de capital humano transferido aos alunos, o que significa um baixo nível de capital humano dos professores no próximo período, e assim por diante. Este trabalho, portanto, fornece uma explicação alternativa do porquê não se observa convergência de renda entre países, mesmo quando as diferenças de outros fatores de produção não são levadas em conta.

Palavras-chaves: capital humano, não-convergência, convergência, escolha ocupacional, qualidade da educação. 



\begin{abstract}
This dissertation assesses the role of education quality in the convergence process of GDP per capita through teachers quality impact in human capital formation. The simple two-period OLG model suggests initial level of teacher's human capital is important to explain non-convergence, even when education quality return is decreasing. This non-convergence arises because an initially low level of teachers' human capital translates into a low level of human capital transfered to students, which means a low level of teachers' human capital in the next period, and so on. This work, therefore, provides an alternative explanation of why countries income do not converge, even when differences in other inputs are not accounted for.
\end{abstract}

Key-words: human capital, non-convergence, convergence, occupational choice, education quality. 



\section{Sumário}

1 Introduction . . . . . . . . . . . . . . . 17

2 The Basic Model . . . . . . . . . . . . . . . . 23

2.1 Individuals . . . . . . . . . . . . . . . . . . . . 23

2.2 Production of final output $\ldots \ldots \ldots \ldots \ldots$

2.3 Government . . . . . . . . . . . . . . . . 26

2.4 Aggregate human capital . . . . . . . . . . . . . . . 27

3 Initial conditions and convergence $\ldots \ldots \ldots \ldots \ldots$

4 Human capital externalities and convergence . . . . . . . 35

5 Comparative dynamics results . . . . . . . . . . 43

5.1 A change in $\theta \ldots \ldots \ldots \ldots \ldots \ldots \ldots$

5.2 A change in $\tau_{M} \ldots \ldots \ldots \ldots \ldots \ldots \ldots$

6 Simulation . . . . . . . . . . . . . . . 49

7 Concluding Remarks . . . . . . . . . . . . . 57

Referências . . . . . . . . . . . . . . 59

Apêndice $A \ldots \ldots \ldots \ldots \ldots \ldots \ldots$ 



\section{Introduction}

Differences in human capital stock have been indicated for decades as one of the major factors that explain why some countries are richer than others. More recently, however, the quality embodied in this human capital stock began to be analyzed more carefully. Hanushek (2013), Hanushek \& Woessmann (2012), Tamura (2001), and Schoellman (2012), just to name a few works, assess the role of human capital quality ${ }^{1}$ on explaining output per worker (or wages, in the latter) variability: quality seems to be at least as important as quantity (empirically and theoretically), and in some specifications much more important than only quantity.

Figure 1 shows that the vast majority of countries have approached the United States in education attainment in the past decades. Thus, one should expect log GDP convergence if human capital quantity is viewed as much more important than others inputs. However, figure 2 shows a stable GDP distribution, with no convergence at all. Along with this fact, Hanushek (2013) presents evidence that when controlling for cognitive skills acquired during education process (a measure of education quality), the initial value of years of schooling does not have any effect on average annual growth rate of GDP per capita in the period 1960-2010.

Growth models that account for education quality, such as Tamura (2001), usually take it as exogenous or as a policy variable that responds to

$1 \quad$ Human capital defined as education (quality and quantity) only, leaving health and other components of a human capital's broader definition aside. 


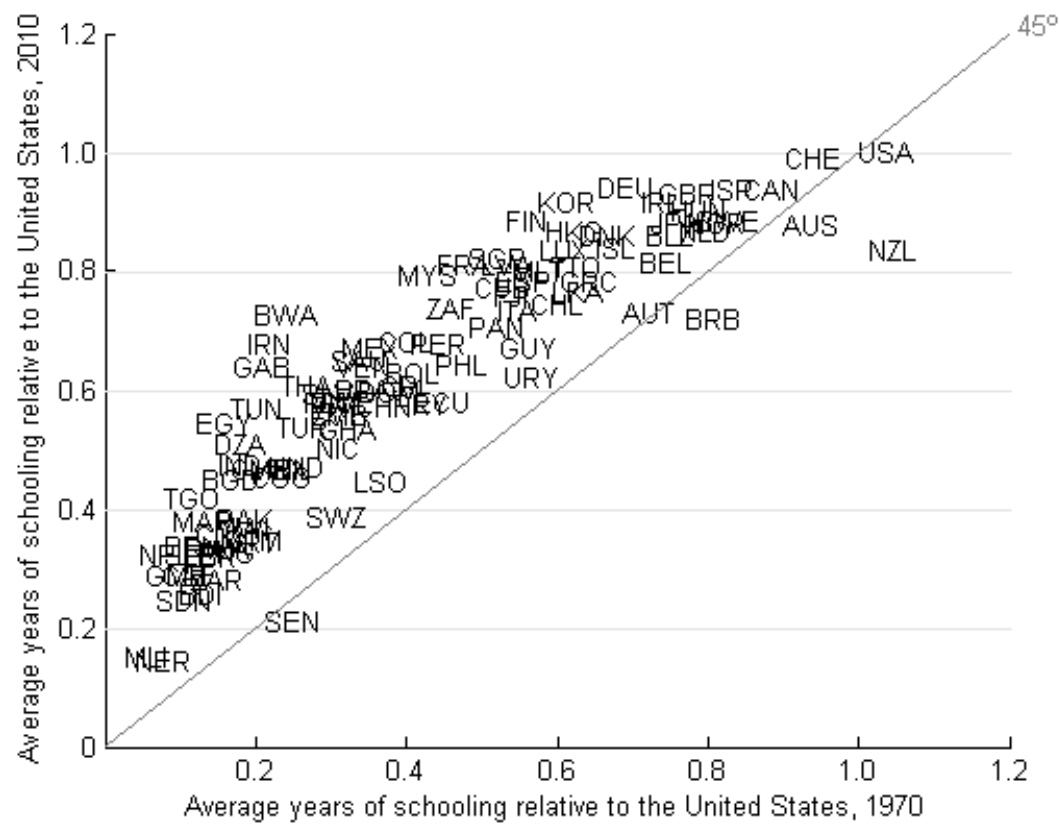

Figure 1 - Average years of schooling in 1970 versus average years of schooling in 2010.

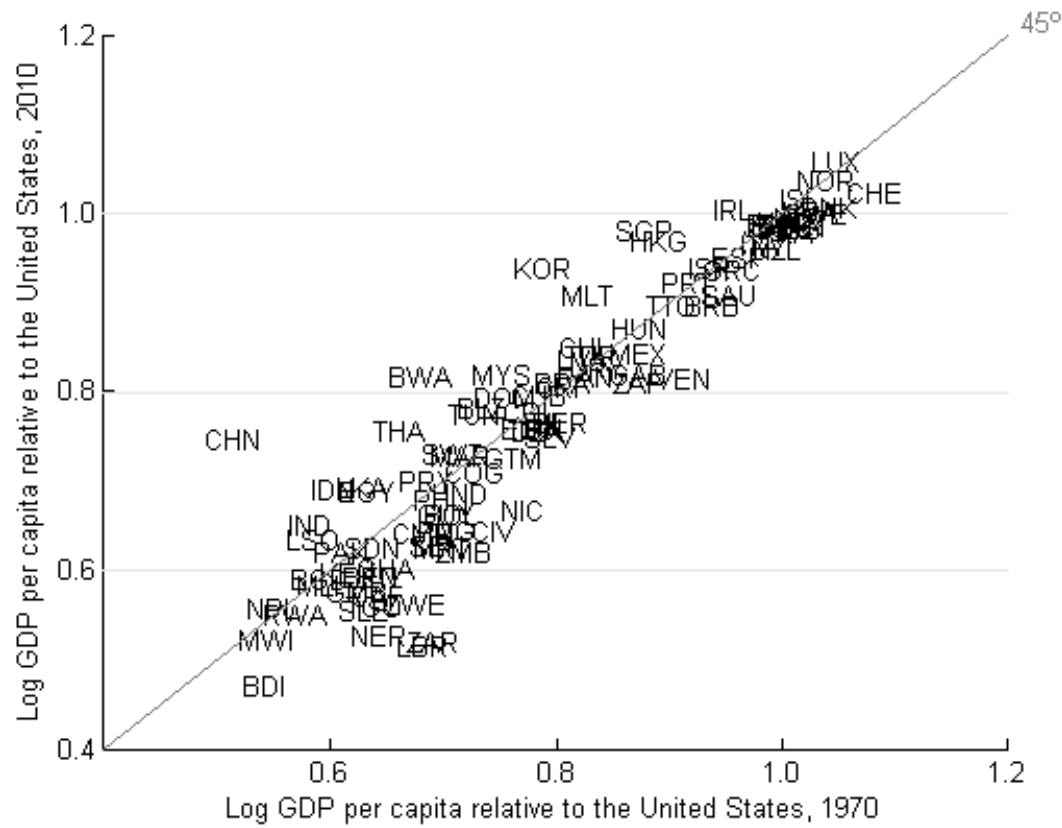

Figure 2 - Log GDP per capita in 1970 versus log GDP per capita in 2010. 
an arbitrary central planner objective function. This paper tries to contribute by making education quality endogenous, which arises through a simple twoperiod OLG model with occupational choice. Similar to Gilpin \& Kaganovich (2012), education quality is measured by average human capital of teachers, with the proportion of teachers on population being assumed to be constant. Convergence process is analyzed with and without the presence of human capital externalities, which is pointed by the literature as an important channel of higher returns to education ${ }^{2}$.

The modeling strategy proposed here differs from previous works when, under some conditions, even when countries differ only in their education quality level we could still observe non-convergence or, at least, convergence to different steady-states values. It is shown that in the presence of a certain kind of human capital externalities, even with decreasing returns to education quality, there could be a multiple steady-state environment, where the initial distribution of human capital in a country could define to which steady-state this country would converge in the long-run. The explanation presented in this paper is that an initially low level of human capital would lead to an initially low level of teachers' human capital, which translates into a low level of human capital transfered to students. Then, some of these students would chose the teacher career in the next period, which would mean a still low level of teachers' human capital, and so on. Thus, under a set of conditions that are presented in the next chapters, the shape of human capital's initial

2 Despite Acemoglu \& Angrist (2000) founding evidence that human capital externalities of high school are statistically insignificant and also not large in magnitude, Iranzo \& Peri (2009) found that social returns of an increase in the proportion of population that have a college degree is significant and of magnitude similar to private returns. 


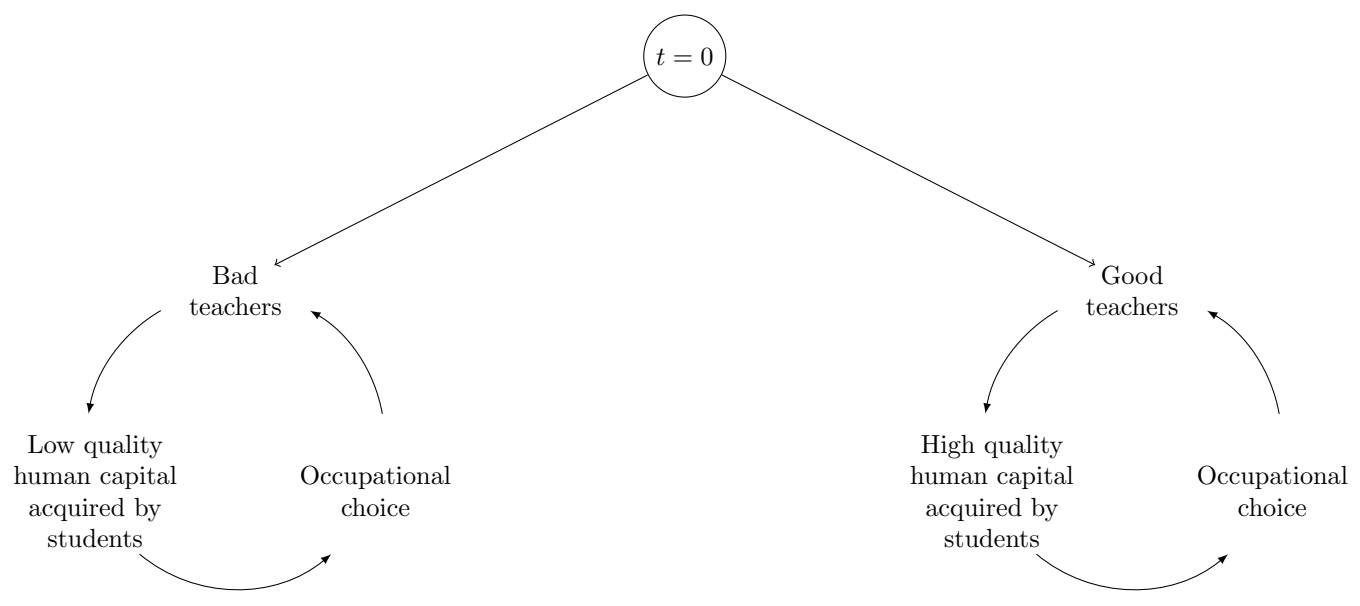

Figure 3 - Cycles of human capital accumulation conditional on initial human capital's distribution.

distribution defines the long-run equilibrium through the channel of education quality. Figure 3 illustrates this mechanism.

Going further and trying to dialog with the "real world"data, we perform a simulation exercise to assess the model and its predictions. With calibration grounded on micro literature evidence and taking USA as benchmark, it is also shown that the required policy through which the poorer country would converge to the steady-state (or growth path) of the richer country, could be too costly for current generations as the consumption level in the period of the policy change would certainly fall. When the education quality return grows, this cost grows too and the required policy could also be unfeasible for a sufficiently high return.

This paper tries to explain the well debated problem of non convergence, but using education quality as the main channel of human capital accumulation and through which multiple steady-states arises. The paper is 
closer to Azariadis \& Drazen (1990) when accounting for human capital externalities, but also dialogs with the literature that deals with non-convergence problem through some market imperfection in OLG models, e.g. Galor \& Zeira (1993) and Galor \& Moav (2004). A similarity between all of these models and the one presented in this paper is the need of a non-convexity in some accumulation function to generate multiple steady-states.

The rest of this paper is organized as follows. Chapter 2 presents the basic model. Chapter 3 describes the initial conditions, its underlying hypothesis and what is the predicted long-run equilibrium. Chapter 4 relies on the same initial conditions to analyze the long-run equilibrium when human capital externalities are accounted for. Chapter 5 draws some comparative dynamics to help us understand the underlying mechanisms through which aggregate variables adjust to policy shocks. Chapter 6 uses calibrated parameters to simulate the model and perform some quantitative exercises, such as policy analysis. Chapter 7 presents conclusions. 



\section{The Basic Model}

\subsection{Individuals}

Consider a simple two-period OLG economy with no population growth and a continuum of individuals of measure 1. Individuals accumulate human capital in the first period and choose a career (teacher or market employee), work and consume their entire income in the second period. Accumulation of human capital is compulsory and taken in public schools. Preferences are identical across individuals and assumed to exhibit a constant relative risk aversion (CRRA):

$$
U_{t}^{i}=\frac{\left(c_{t}^{i}\right)^{1-\sigma}-1}{1-\sigma} \quad \text { subject to } \begin{cases}c_{t}^{i} \leq\left(1-\tau_{M}\right) \cdot w_{t}^{M} \cdot h_{t}^{i}+\phi_{t}, & \text { if } i \in M \\ c_{t}^{i} \leq\left(1-\tau_{T}\right) \cdot w_{t}^{T}+\phi_{t}, & \text { if } i \notin M\end{cases}
$$

where $\sigma>0, \tau_{M}$ and $\tau_{T}$ are income tax rates, $i \in M$ means that individual $i$ works at the private market and $i \notin M$ means that individual $i$ works as a teacher. $\phi_{t}$ is a lump-sum transfer granted by government according to its budget constraint. Note that all teachers earn the same income independently of their human capital level $h_{t}^{i}$, which is in accordance with the teacher's hiring process presented later in the text.

Individuals, however, may differ in their innate ability $a_{t}^{i}$, which is distributed uniformly over the interval $[0, \bar{B}]^{1}$. This innate ability is a compo-

1 This assumption of uniform distribution follows Galor \& Moav (2000) and Gilpin \& 
nent of human capital accumulation function along with education quality, which is given by average human capital of individuals that have chosen to be teachers in previous period $\left(h_{t-1}^{T}\right)$. Thus,

$$
h_{t}^{i}=C_{t} \cdot a_{t}^{i} \cdot\left(h_{t-1}^{T}\right)^{v}
$$

where $v>0$, and $C_{t}$ is a time-dependent productivity term, which is assumed to be constant when externalities are not acting and is assumed to be a function of aggregate human capital when externalities are present. Given this structure of preferences and human capital accumulation, individuals will choose what career to take as a response to their level of human capital and so to their level of innate ability. The analysis of the individual who is indifferent between choosing teacher career or market career give us the innate ability threshold which define who will be part of teachers group and market group.

$$
\begin{gathered}
U_{t}^{i M}=U_{t}^{i T} \Longleftrightarrow\left(1-\tau_{M}\right) \cdot w_{t}^{M} \cdot h_{t}^{i}=\left(1-\tau_{T}\right) \cdot w_{t}^{T} \\
a_{t}^{\star}=\frac{\left(1-\tau_{T}\right) \cdot w_{t}^{T}}{\left(1-\tau_{M}\right) \cdot w_{t}^{M}} \cdot \frac{1}{C_{t} \cdot\left(h_{t-1}^{T}\right)^{v}}
\end{gathered}
$$

Therefore, everyone who has a level of innate ability such that $a_{t}^{i}>a_{t}^{\star}$ will choose to be part of private market. All individual $i$ who has $a_{t}^{i}<a_{t}^{\star}$

Kaganovich (2012). 


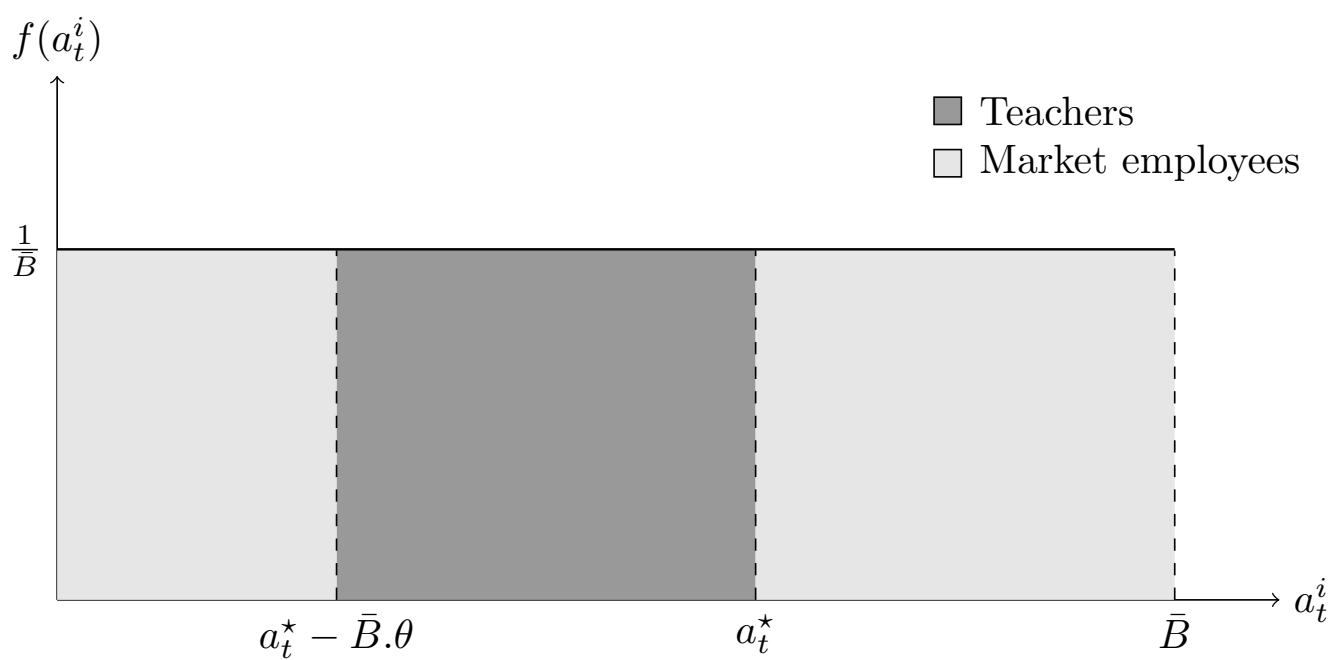

Figure 4 - Probability density function of innate ability. The dark grey area is the proportion $\theta$ of teachers in the population. Every individual whose innate ability is outside this dark grey area will be a market employee.

would chose to be a teacher, but we impose as a restriction that the fraction of teachers in the population is constant and equal to $\theta$ for every $t$. This restriction can be thought as a physical restriction: for a given educational infrastructure (e.g., a given number of schools), the government must hire $\theta$ teachers to make its educational system work properly. It can not hire less than $\theta$ and would not be able to accommodate more than $\theta$. In addition, these $\theta$ teachers are hired through a public tender that occurs in every period and offers only $\theta$ jobs, which, through competition among all applicants, are filled by the $\theta$ most qualified individuals. Figure 4 shows what this constant $\theta$ implies: all individuals with a sufficiently low level of innate ability will be market employees despite their initial desire of being teachers, since all $\theta$ teachers would have already been hired. 


\subsection{Production of final output}

Production is described by:

$$
Y_{t}=A_{t} \cdot H_{t}^{\beta}
$$

where $H_{t}=\int_{i \in M} h_{t}^{i}$.di, $A_{t}$ is the exogenous level of aggregate productivity at time $t$ and $\beta \in(0,1]$. Thus, the marginal productivity of human capital (and also market wage as we assume perfect competition and profit maximization) is given by:

$$
w_{t}^{M}=A_{t} \cdot \beta \cdot H_{t}^{\beta-1}
$$

\subsection{Government}

Teachers are hired by a government that collects a $\tau_{M}$ fraction of market employees income and a $\tau_{T}$ fraction of teachers income. As a policy choice, government spends a $p_{t}$ fraction of all its tax revenue paying teachers and $1-p_{t}$ with a lump-sum transfer that complements consumers' income in equation (2.1), but does not affect occupational choice process. Despite the fact that $p_{t}$ can vary with time (e.g., following a government policy of gradual increase in teachers' salaries), we assume a constant $p_{t}=p$ throughout the paper. Thus, the government budget constraint is given by: 


$$
\left(\tau_{M} \cdot w_{t}^{M} \cdot H_{t}+w_{t}^{T} \cdot \tau_{T} \cdot \theta\right) \cdot p=\theta \cdot w_{t}^{T}
$$

Teacher's salary $\left(w_{t}^{T}\right)$ can be set as a function of other variables and parameters so that

$$
w_{t}^{T}=\frac{p \cdot \tau_{M} \cdot w_{t}^{M} \cdot H_{t}}{\theta \cdot\left(1-p \cdot \tau_{T}\right)}
$$

Notice that despite $w_{t}^{T}$ being the same for all teachers, it evolves according to the whole economy: given equation (2.4), the salary of teachers will be higher the higher economy's $Y_{t}$. Therefore, given model parameters and government budget constraint, $w_{t}^{T}$ will evolve endogenously.

\subsection{Aggregate human capital}

Aggregate human capital is obtained by simply integrating the individual human capital function in the ability interval that defines who works at the market and who works as teacher.

$$
\begin{gathered}
H_{t}=\int_{0}^{a_{t}^{\star}-\bar{B} \cdot \theta} h_{t}^{i}\left(a_{t}^{i}\right) \cdot d F\left(a_{t}^{i}\right)+\int_{a_{t}^{\star}}^{\bar{B}} h_{t}^{i}\left(a_{t}^{i}\right) \cdot d F\left(a_{t}^{i}\right) \\
h_{t}^{T}=\theta^{-1} \cdot \int_{a_{t}^{\star}-\bar{B} \cdot \theta}^{a_{t}^{\star}} h_{t}^{i}\left(a_{t}^{i}\right) \cdot d F\left(a_{t}^{i}\right)
\end{gathered}
$$


Hence, it follows from (2.3)-(2.5) (see Appendix A) that

$$
\begin{gathered}
H_{t}=\frac{C_{t} \cdot \bar{B}}{2} \cdot M \cdot\left(h_{t-1}^{T}\right)^{v} \\
h_{t}^{T}=\frac{C_{t} \cdot \bar{B}}{2 \cdot \theta} \cdot[1-M] \cdot\left(h_{t-1}^{T}\right)^{v}
\end{gathered}
$$

where $M \equiv\left[\frac{\left(1+\theta^{2}\right) \cdot\left(1-p \cdot \tau_{T}\right) \cdot\left(1-\tau_{M}\right)}{\left(1-p \cdot \tau_{T}-\tau_{M} \cdot(1-p)\right)}\right]$.

Since aggregate human capital of whole population (teachers and market employees) is obtained by taking the integral of individual human capital function over the whole ability interval, we can represent it by the sum $H_{t}+\theta \cdot h_{t}^{T}$, which is equal to $\frac{C_{t} \cdot \bar{B}}{2} \cdot\left(h_{t-1}^{T}\right)^{v}$. Then, equation (2.6) shows that $H_{t}$ is a constant fraction $M$ of whole population's aggregate human capital. However, what is the intuition behind $M$ ?

For simplicity, let's assume for a moment that $p=1$. In this case, $M$ will be reduced to $\left(1+\theta^{2}\right) \cdot\left(1-\tau_{M}\right)$, which represents the incentives that individuals face in the occupational choice process. Note that for a greater $\theta$, the same government budget will pay less for each teacher and the teacher career will be less attractive to all individuals in $t$, including those with higher values for innate ability. Therefore, $H_{t}$ will be higher through a greater $M$, and the average teacher will be less qualified for the same reason. Nevertheless, a greater $\tau_{M}$ will act on the contrary direction, making the market career less attractive in $t: H_{t}$ will be smaller due to a smaller $M$.

Going further, a technical assumption about innate ability threshold 
is required in order to guarantee that we will have $\theta$ teachers in all periods, to guarantee that the dark grey area in figure 4 will be equal to $\theta$.

Assumption 1. (Assumption to guarantee $\theta$ teachers for every $t$ ). This constant $\theta$ can be translated into the inequality in which $\theta . \bar{B}<a_{t}^{\star}<\bar{B}$, i.e., $a_{t}^{\star}$ must be in the middle of the innate ability distribution ${ }^{2}$.

Finally, under Assumption (1), the complete solution of the model depends only on initial values for $h_{0}^{T}$ and a function which defines $C_{t}$.

2 Plugging equations (2.5) and (2.6) into equation (2.3), we can restate $\theta \cdot \bar{B}<a_{t}^{\star}<\bar{B}$ as

$$
2 . \theta^{2}<\frac{\left(1-\tau_{T}\right) \cdot p}{\left(1-p \cdot \tau_{T}-\tau_{T} \cdot \tau_{M} \cdot(1-p)\right)} \cdot \tau_{M} \cdot\left(1+\theta^{2}\right)<2 . \theta
$$

World Bank Databank shows that over $70 \%$ of countries with data on income tax obey this inequality when $p$ is assumed to be 1 . 



\section{Initial conditions and convergence}

Let's assume that individuals' human capital on $t=0$ (i.e., $h_{0}^{i}$ ) is distributed uniformly over the interval $[x-\lambda ; x+\lambda]$ such that $E\left[h_{0}^{i}\right]=x$ and $\operatorname{Var}\left[h_{0}^{i}\right]=\frac{\lambda^{2}}{3}$. Using the human capital threshold of career choice, given by relative (teacher-market) income, and equation $(2.5), h_{0}^{T}$ can be restated as a function only of structural parameters, fraction $p, x$ and $\lambda$ (see Appendix A for all steps).

$$
\begin{aligned}
h_{0}^{T}=\frac{\left(1-\tau_{T}\right) \cdot p}{\left(1-p \cdot \tau_{T}-\tau_{M} \cdot(1-p)\right)} & \frac{\tau_{M} \cdot x}{\theta} \\
& -\left(1-\tau_{M}\right) \cdot \theta \cdot \lambda \cdot \frac{\left(1-p \cdot \tau_{T}\right)}{\left(1-p \cdot \tau_{T}-\tau_{M} \cdot(1-p)\right)}
\end{aligned}
$$

The model structure presented so far, along with initial conditions given by equation (3.1) above and the assumption of $C_{t}=C$ for now, leads to the following result:

Proposition 1. (Convergence process under $C_{t}=C$, and different initial $\left.h_{0}^{T}\right)$. Consider two economies that are identical in all aspects except for their initial level of teacher's human capital, which can be result of different $x$ and/or $\lambda$. Given these different initial conditions:

1. $v \in(0,1)$ : both economies would converge to the same unique steadystate equilibrium.

2. $v \geq 1$ : divergence would take place if 


$$
\frac{C . \bar{B}}{2 . \theta} \cdot[1-M]>1
$$

Proof. Since all model's dynamics are driven by the $h_{t}^{T}$ evolution, its behavior is a necessary and suficient condition to define behavior of all real variables. Growth of $h_{t}^{T}$ is given by:

$$
g\left(h_{t-1}^{T}\right) \equiv \frac{h_{t}^{T}}{h_{t-1}^{T}}=\frac{C \cdot \bar{B}}{2 \cdot \theta} \cdot[1-M] .\left(h_{t-1}^{T}\right)^{v-1}
$$

1. $v \in(0,1)$.

By definition, $h_{s s}^{T}$ is a steady state if and only if $g\left(h_{s s}^{T}\right)=1$, i.e. $h_{t}^{T}=$ $h_{t-1}^{T}=h_{s s}^{T}$. Since $\lim _{h^{T} \rightarrow 0} g\left(h^{T}\right)=\infty, \lim _{h^{T} \rightarrow \infty} g\left(h^{T}\right)=0$ and $g($.$) is a$ continuous function, by the Intermediate Value Theorem there is a $h_{s s}^{T}$ such that $0<g\left(h_{s s}^{T}\right)=1<\infty$. Moreover, note that $g($.$) is everywhere$ decreasing, i.e. $\partial g\left(h^{T}\right) / \partial h^{T}<0 \forall h^{T} \in(0, \infty)$. Therefore, there can only exist a unique $h_{s s}^{T}$ such that $g\left(h_{s s}^{T}\right)=1$. Every country with the same structural and policy parameters will converge to this $h_{s s}^{T}$, regardless the initial conditions.

2. $v \geq 1$.

In this case, $g\left(h^{T}\right)>1 \forall h^{T} \geq 1$. For countries with the same structural and policy parameters, but with different initial conditions, divergence would take place, since an initial difference would persist (or even be amplified) through a $g\left(h^{T}\right)$ that is 
- equal across countries if $v=1$.

- always higher for an initially richer country if $v>1$.

Proposition 1, however, does not bring any result that has not already been obtained in the literature: figure 5 shows the well known case of convergence when we have decreasing returns in the human capital accumulation function. The next chapter, which introduces the human capital externality idea, is more insightful. 


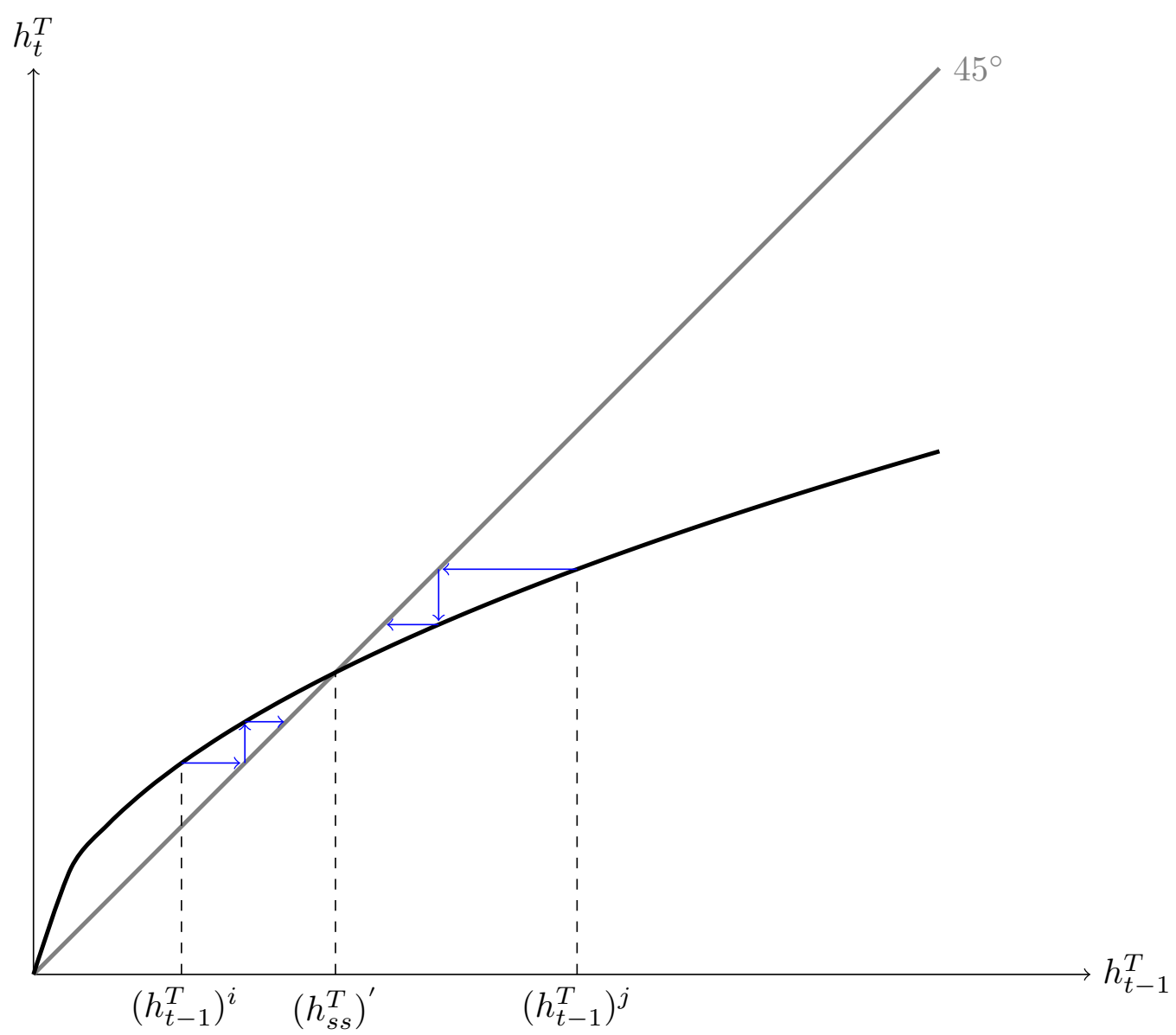

Figure 5 - Average teachers' human capital evolution when $v \in(0,1)$ according to equation (2.7). Both country $i$ and country $j$ converge to the same and unique steady-state equilibrium. 


\section{Human capital externalities and convergence}

It is usual to assume that aggregate human capital generates some kind of externality to the individual earnings, although the magnitude and at which point externality begins to act remains unclear. Acemoglu \& Angrist (2000) present evidence that this externality isn't strong in magnitude when dealing with changes in secondary schooling. Iranzo \& Peri (2009) reinforce this result about changes in secondary schooling, but show that there is strong and statistically significant external returns to education when there are positive changes in higher education. This comes from the fact that highly educated workers may facilitate the adoption of better and more productive technologies. However, for a sufficiently high level of aggregate human capital, children's accumulation of human capital could also benefit from more skilled teachers, parents, neighbors, etc. that would be able to help them in the learning process, which is subject to the adoption of newer technologies too. Therefore, the presence of this externality could boost not only the Total Factor Productivity of an economy (Iranzo \& Peri (2009)) but also the accumulation of human capital itself ${ }^{1}$.

Following this evidence, we now assume externality plays a role in the model and begins to act when human capital is above a certain threshold ${ }^{2}$. This externality is introduced via $C_{t}$, which is defined as a function of aggregate human capital of whole population ${ }^{3}$ such that

$\overline{1}$ See Acemoglu (1996) for a model where the rate of return on human capital is increasing in the average human capital of the workforce but not through effects in the TFP.

2 This threshold externality structure is directly related to Azariadis \& Drazen (1990)

3 Just as showed in section 2.4 , this is given by $H_{t}+\theta \cdot h_{t}^{T}=\frac{C_{t} \cdot \bar{B}}{2} \cdot\left(h_{t-1}^{T}\right)^{v}$ 


$$
C_{t}=D \cdot\left(\frac{C_{t} \cdot \bar{B} \cdot\left(h_{t-1}^{T}\right)^{v}}{2}\right)^{\gamma}
$$

and, thus,

$$
C_{t}=D^{\frac{1}{1-\gamma}} \cdot\left(\frac{\bar{B}}{2}\right)^{\frac{\gamma}{1-\gamma}} \cdot\left(h_{t-1}^{T}\right)^{\frac{v \cdot \gamma}{1-\gamma}} \quad \forall t \text { when } E\left[h_{t}^{i}\right] \geq \bar{h}
$$

where $\gamma \in(0,1)$ and $D$ is an arbitrary positive constant. Thus, $C_{t}$ will have a discontinuity point at the human capital threshold defined as $\bar{h}$.

$$
C_{t}= \begin{cases}C & \text { if } E\left[h_{t}^{i}\right]<\bar{h} \\ D^{\frac{1}{1-\gamma}} \cdot\left(\frac{\bar{B}}{2}\right)^{\frac{\gamma}{1-\gamma}} \cdot\left(h_{t-1}^{T}\right)^{\frac{v \cdot \gamma}{1-\gamma}} & \text { if } E\left[h_{t}^{i}\right] \geq \bar{h}\end{cases}
$$

When $\bar{h}$ is sufficiently high this strutcure is in accordance with empirical evidence of statistically insignificant external returns to secondary school but statistically significant external returns to schooling at higher levels, since for an initially high level of human capital and a given distribution variance a positive change in the average human capital of the whole population means, with high probability, an increase in the proportion of college graduates.

Therefore, $h_{t}^{T}$ and $H_{t}$ are given by

$$
h_{t}^{T}= \begin{cases}\frac{C}{\theta} \cdot \frac{\bar{B}}{2} \cdot[1-M] \cdot\left(h_{t-1}^{T}\right)^{v} & \text { if } E\left[h_{t}^{i}\right]<\bar{h} \\ \frac{D^{1-\gamma}}{\theta} \cdot\left(\frac{1}{2}\right)^{\frac{1}{1-\gamma}} \cdot[1-M] \cdot\left(h_{t-1}^{T}\right)^{\frac{v}{1-\gamma}} & \text { if } E\left[h_{t}^{i}\right] \geq \bar{h}\end{cases}
$$




$$
H_{t}= \begin{cases}C \cdot \frac{\bar{B}}{2} \cdot M \cdot\left(h_{t-1}^{T}\right)^{v} & \text { if } E\left[h_{t}^{i}\right]<\bar{h} \\ D^{\frac{1}{1-\gamma}} \cdot\left(\frac{\bar{B}}{2}\right)^{\frac{1}{1-\gamma}} \cdot M \cdot\left(h_{t-1}^{T}\right)^{\frac{v}{1-\gamma}} & \text { if } E\left[h_{t}^{i}\right] \geq \bar{h}\end{cases}
$$

Note that this discontinuity in equations (4.2) and (4.3), along with different initial conditions, could lead to an environment where countries would converge to different growth paths or non-zero steady-state values: this phenomenon has been recently defined as the middle-income trap. Despite the development of literature on middle-income trap being recent, Eichengreen, Park \& Shin (2013) and Aiyar et al. (2013) try to assess what variables constitute active restraints to further growth in middle-income countries that have fallen in this trap. Eichengreen, Park \& Shin (2013) also present evidence that human capital level is a determinant in growth slowdowns episodes, which is in accordance with the externality structure proposed here.

Following this definition and the presence of externality, the proposition below sums up the main result of the paper.

Proposition 2. (Convergence process under the presence of aggregate human capital externality, and different initial $\left.h_{0}^{T}\right)$. Consider two economies that are identical in all aspects except for their initial level of teachers' human capital, which can be result of different $x$ and/or $\lambda$ for example. These different initial conditions could lead to different steady-state equilibria, which would translate into a middle-income trap, if:

1. $v \in(0,1)$ : 
a) Human capital externality isn't strong enough to promote nondecreasing returns, i.e., $v+\gamma<1$, but is sufficiently high to guarantee that

$$
\frac{D^{\frac{1}{1-\gamma}}}{\theta} \cdot\left(\frac{\bar{B}}{2}\right)^{\frac{1}{1-\gamma}} \cdot[1-M]>\left(\bar{h}^{T}\right)^{\frac{1-\gamma-v}{1-\gamma}}
$$

b) Human capital externality is strong enough to guarantee nondecreasing returns to education quality, i.e., $v+\gamma \geq 1$, and constants are such that

$$
\frac{D^{\frac{1}{1-\gamma}}}{\theta} \cdot\left(\frac{\bar{B}}{2}\right)^{\frac{1}{1-\gamma}} \cdot[1-M]>1
$$

2. $v \geq 1$ : divergence would take place just as in the model without externality, but differences in the long run GDP could be amplified.

Proof. This follows almost immediately from proof of Proposition 1 with only some particularities.

1. $v \in(0,1)$.

a) $v+\gamma<1$

Following the same steps of the first part of Proposition 1, there are two values for $h_{s s}^{T}$ where $g()=$.1 : a low $h_{s s}^{T}$ in the interval given by $\left[0, \overline{h^{T}}\right)$ and a high $h_{s s}^{T}$ in the interval given by $\left[\overline{h^{T}}, \infty\right)$. Thus, $h_{0}^{T}$ define, in the absence of any parameters change, to which of these two steady-states the economy would converge. 
b) $v+\gamma \geq 1$

In this case, there is a steady-state $h_{s s}^{T}$ value in the interval given by $\left[0, \overline{h^{T}}\right)$, but $g()>.1 \forall h^{T}$ values in the interval $\left[\overline{h^{T}}, \infty\right)$. Therefore, countries with a $h_{0}^{T}<\overline{h^{T}}$ would converge to $h_{s s}^{T}$, but countries with a greater $h_{0}^{T}$ would grow indefinitely.

2. $v \geq 1$.

Just as in Proposition 1, when $v$ is sufficiently high, divergence would take place if we face countries with different initial conditions. However, the presence of externality amplifies the distance between the poorer and the richer country in comparison to the case without externality, since the initially richer country would grow faster for at least one period $\left(\frac{v}{1-\gamma}>v\right)$.

Proposition 2 shows that when there is an aggregate human capital externality in the individual human capital accumulation function, if this externality is strong enough (but not necessarily strong enough to generate non-decreasing returns) countries that have an initially low average human capital (or even an extremely unequal initial distribution of human capital) would converge to a steady-state in the long-run that is lower than the steadystate to which a country that have better initial conditions would converge. This non-convergence is result of the human capital transfer effect through which bad teachers in the present make bad teachers and also less skilled 
workers in the future (see figure 3). The fact that non-convergence arises with differences only in education quality, all else assumed being equal, is the main contribution of this paper

To illustrate this, figures 6 and 7 show two cases where the presence of this externality makes convergence (to an unique steady-state) of the same countries $i$ and $j$ in figure 5 unfeasible. 


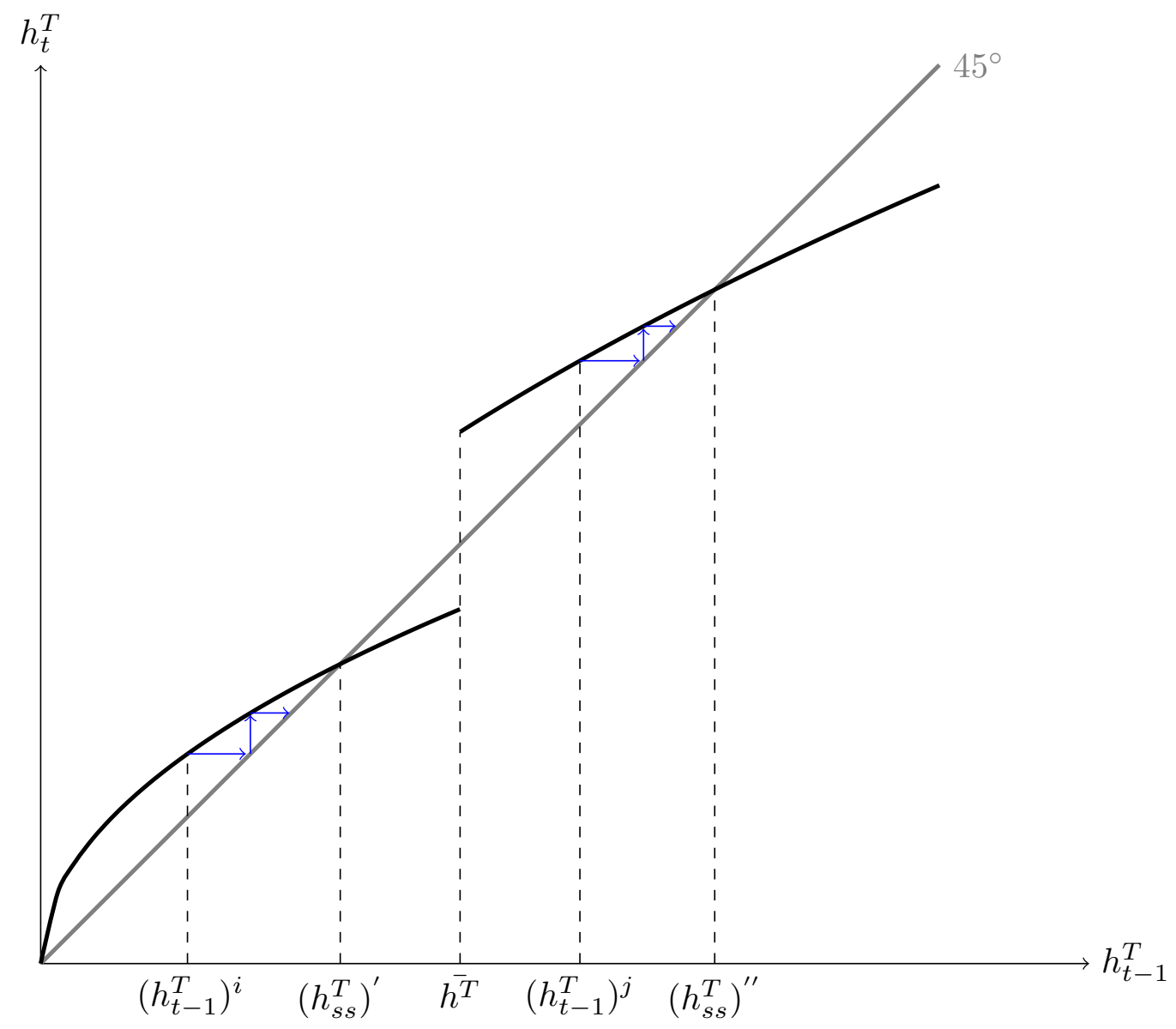

Figure 6 - Average teachers human capital evolution under the presence of aggregate human capital externality with $v+\gamma<1$ according to equation (4.2). Now country $i$ converge to the same steady-state equilibrium as before but country $j$ converge to a higher steady-state equilibrium. There isn't convergence to the same steady-state in this case. 


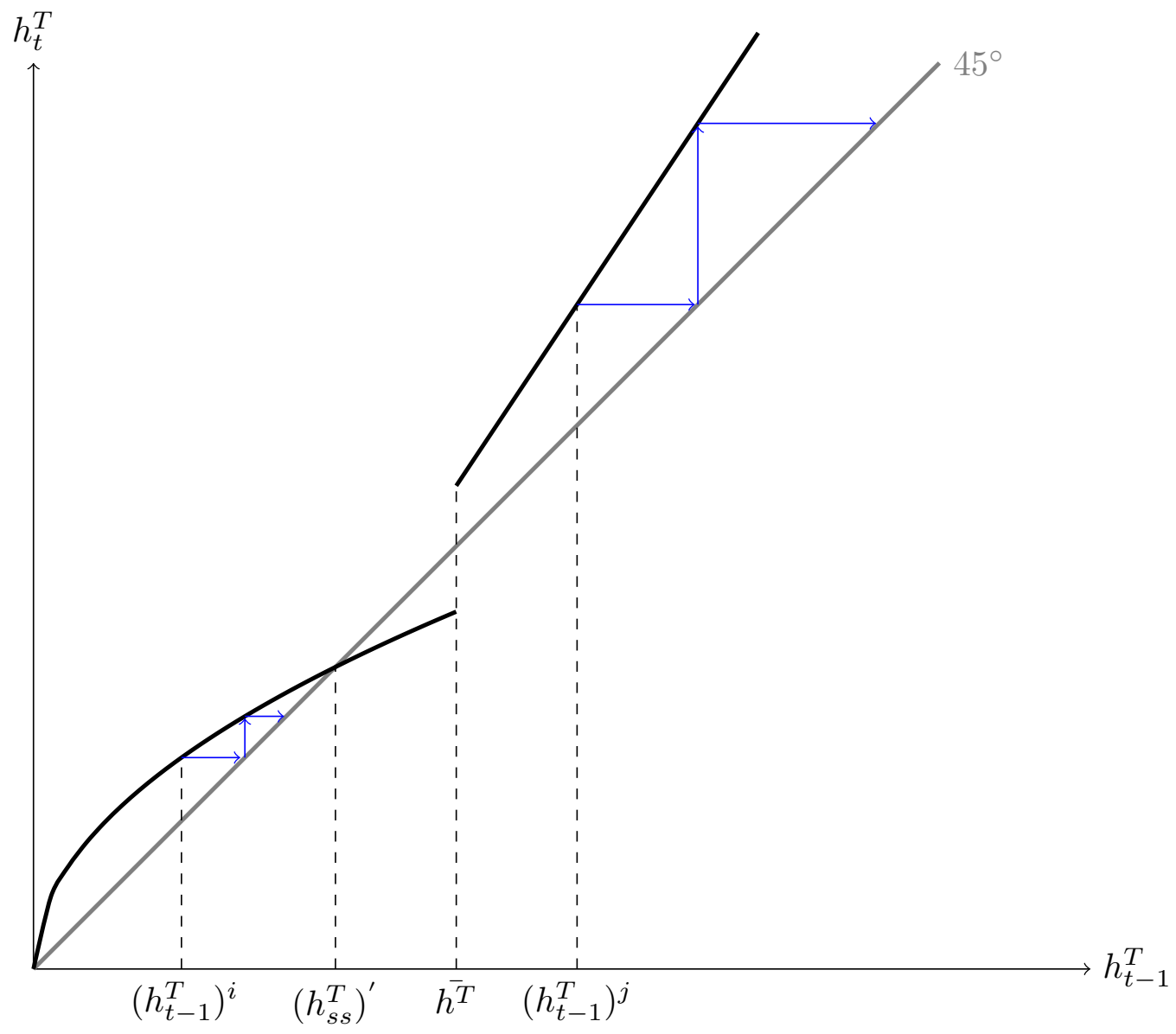

Figure 7 - Average teachers human capital evolution under the presence of aggregate human capital externality with $v+\gamma=1$ according to equation (4.2). Now country $i$ converge to the same steady-state equilibrium as before but country $j$ grows at a permanently constant rate given by parameters, just as in AK model. 


\section{Comparative dynamics results}

Our main interest in this chapter is to understand what are the tradeoffs that some policies are subject to, mainly when a poorer country is aiming convergence to the steady-state's GDP per capita level of a richer country. Moreover, we would like to understand the mechanisms through which these trade-offs arise. Therefore, we would like to answer questions such as: $i$ ) what are the mechanisms through which government decisions affect individuals' occupational choice? $i i$ ) does a change in the proportion of teachers in the population (which can be thought as a measure of human capital's quantity) affect the human capital's quality? iii) does a change in the income tax rate and/or in the proportion of the government's budget spent with teachers' salaries affect the human capital's quality? iv) what are the costs to current generations of a policy that aims to reach a higher steady-state equilibrium in the long-run? ${ }^{1}$

Note that all model's dynamics come from the evolution of teachers' average quality, which is deeply affected by the process of occupational choice and, therefore, by the parameters which define who, in the innate ability's distribution, will be a teacher. In order to assess this question, use equation (2.3) and substitute equations (2.5) and (2.6) to reach:

$$
a^{\star}=\frac{\left(1-\tau_{T}\right) \cdot p}{\theta \cdot\left(1-p \cdot \tau_{T}\right)} \cdot \frac{\tau_{M}}{\left(1-\tau_{M}\right)} \cdot \frac{\bar{B}}{2} \cdot M
$$

$1 \quad$ All results, and especially derivatives signs, presented in this chapter are easily obtained noting that $M>0, \theta \in(0,1), \tau_{M}$ and $\tau_{T}$ are both in the interval $(0,1)$, and proportion $p \in(0,1]$. Derivation steps, however, are available upon request. 
where $M$ has already been defined as being equal to $\left[\frac{\left(1+\theta^{2}\right) \cdot\left(1-p \cdot \tau_{T}\right) \cdot\left(1-\tau_{M}\right)}{\left(1-p \cdot \tau_{T}-\tau_{M} \cdot(1-p)\right)}\right]$. Note that this $M$ definition implies that: $\frac{\partial M}{\partial \theta}>0, \frac{\partial M}{\partial \tau_{M}}<0$, and $\frac{\partial M}{\partial p}<0$. Following these derivatives signs, we are able to answer how policy shocks affect individuals' occupational choice through changes on the innate ability threshold $a^{\star}$ :

$$
\frac{\partial a^{\star}}{\partial \theta}<0, \quad \frac{\partial a^{\star}}{\partial \tau_{M}}>0, \quad \frac{\partial a^{\star}}{\partial p}>0
$$

Note that, just as previously discussed for the case when $p=1$, a greater $\theta$ will make the teacher career less attractive to all individuals: $\frac{\partial a^{\star}}{\partial \theta}<0$. The same government budget will have to be divided by a larger number of teachers, i.e., government will pay less for each teacher and the individual that was indifferent between career options will now strictly prefer the market career.

Changes in $\tau_{M}$ and $p$ also impact the occupational choice's process through the innate ability's threshold. Note that a greater $\tau_{M}$ will make the market career less attractive since government will require a greater income tax from those that work as a market employee. A greater $\tau_{M}$ means that potential teachers will face a worse outside option in the market. This fact is in accordance with Nagler, Piopiunik \& West (2015) evidence: they show that more able individuals prefer teacher career during recessions due to a weaker private market and, therefore, lower expected earnings in non-teacher occupations. A greater $p$ will also affects positively $a^{\star}$, just as a greater $\tau_{M}$, but by making earnings in the teacher career higher and not earnings in the 
private market lower. However, both changes in $\tau_{M}$ and $p$ affect occupational choice by modifying relative earnings (teacher/market) in the same direction.

But what about the effect of these policies in aggregate variables, especially in teachers' quality and in the GDP per capita evolution?

\subsection{A change in $\theta$}

Taking the partial derivative of equations (2.7) and (2.6) with respect to $\theta$ can help us understand how the proportion of teachers in the population affects teachers' quality $h_{t}^{T}$ and, therefore, how it affects $H_{t}$, which is the main component of GDP per capita. Thus,

$$
\frac{\partial h_{t}^{T}}{\partial \theta}<0, \quad \frac{\partial h_{t+1}^{T}}{\partial \theta}<0, \quad \frac{\partial H_{t}}{\partial \theta}>0, \quad \frac{\partial H_{t+1}}{\partial \theta} \lessgtr 0
$$

Note that derivatives of $h_{t}^{T}$ show a trade-off between quantity and quality of human capital: an increase in $\theta$ leads to a reduction in $h_{t}^{T}$. Intuitively, a government decision of hiring a greater number of teachers $(\theta \uparrow)$, in a public tender hiring process, will mean more positions being filled by the same pool of candidates, and, therefore, a lower competition among candidates, which will translate into a lower average quality of hired teachers ${ }^{2}$. In the long-run, this higher $\theta$ will lead to a lower steady-state value for the teachers' average quality, since government will hire, period after period, less qualified teachers on average.

2 Despite being generated by other mechanisms, this quantity-quality trade-off is also discussed in Gilpin \& Kaganovich (2012). 
The impact of a higher $\theta$ over $H_{t}$, however, is not uniform along time: despite a positive impact in the period of the policy change and an undefined impact in the near generations, in the long-run a lower teachers' average quality (due to this higher $\theta$ ) will lead to an also lower aggregate human capital of non-teachers. Therefore, an increase in the proportion of teachers in the population, despite its short-run positive impacts, will lead an initially poor country to an even lower steady-state equilibrium.

\subsection{A change in $\tau_{M}$}

In order to understand how income tax rate affects teachers' quality and $H_{t}$, consider a change in $\tau_{M}$, with all other parameters held constant. Thus, partial derivative of equations (2.7) and (2.6) yields

$$
\frac{\partial h_{t}^{T}}{\partial \tau_{M}}>0, \quad \frac{\partial h_{t+1}^{T}}{\partial \tau_{M}}>0, \quad \frac{\partial H_{t}}{\partial \tau_{M}}<0, \quad \frac{\partial H_{t+1}}{\partial \tau_{M}} \lessgtr 0
$$

Unlike changes in $\theta$, an increase in $\tau_{M}$ will lead to a greater teachers' average quality in $t$ and also in the long-run. A higher $\tau_{M}$ affects the attractiveness of market career by increasing relative (teacher/market) earnings, and, then, pushing away the more able applicants from the market $\left(\frac{\partial a^{\star}}{\partial \theta}>0\right)$. For a given $\theta$, this new $\tau_{M}$ will dislocate the teachers' area in figure 4 to the right and, therefore, will lead to an also higher $h_{t}^{T}$. The steady-state value of teachers' average quality will be higher and can also be sufficient to make a poor country escape from the middle-income trap imposed by its initial 
conditions.

However, a higher $\tau_{M}$ has negative impacts over current generations by lowering individual income and, therefore, individual consumption level. Despite the positive long-run impact in $H_{t}$ through a higher $h_{t}^{T}$, the cost of an increase in income tax rate for current generations can be high enough to make it unfeasible politically if government policy is subject to the median voter choice, for example ${ }^{3}$.

3 Changes in $p$ have all the same effects of $\tau_{M}$ and arise through the same channels. 



\section{Simulation}

We will now go through a calibration effort in order to simulate the model and perform some quantitative exercises. Parameters of policy are taken from USA data, which constitute our benchmark economy, and education quality return, human capital threshold and externality parameter are calibrated according to micro literature evidence. To focus only in education quality differences, $A_{t}$ is normalized so that $A_{t}=A=1$, but we maintain it in the model so that questions about exogenous technological shocks could be addressed in future research. We describe all calibration steps below, whose values are summarized in table 1.

The elasticity of output with respect to human capital $(\beta)$ is set to match the same elasticity in Erosa, Koreshkova \& Restuccia (2010) model, where it is equal to two thirds. Preference parameter $\sigma$ is set to 2, just as in Erosa, Koreshkova \& Restuccia (2010) too, given the similar model period ${ }^{1}$. The proportion of teachers $\theta$ is defined as the inverse of the well-known pupil-teacher ratio in the public elementary and secondary education, which is equal to $6.51 \%$ according to the equilibrium value of this pupil-teacher ratio in the US (figure 8) ${ }^{2}$. The income tax rate, which we assume being the same to market employees and teachers, is set to $9.92 \%$ according to $1970-2010$ average of the individuals plus corporations income taxes as percentage of

1 Erosa, Koreshkova \& Restuccia (2010) model is a 3-period OLG, so they set the model period to 20 years to reach an individual life expectancy of 60 years. Since individuals live only two periods in our model the model period is set to 30 years to reach the same life expectancy of 60 years.

2 Data available at the National Center of Education Statistics website: < https://nces. ed.gov/programs/digest/d13/tables/dt13_208.20.asp >. The 1993-2010 average of the same pupil-teacher ratio available in World Bank Databank gives a similar $\theta$ of $6.72 \%$. 


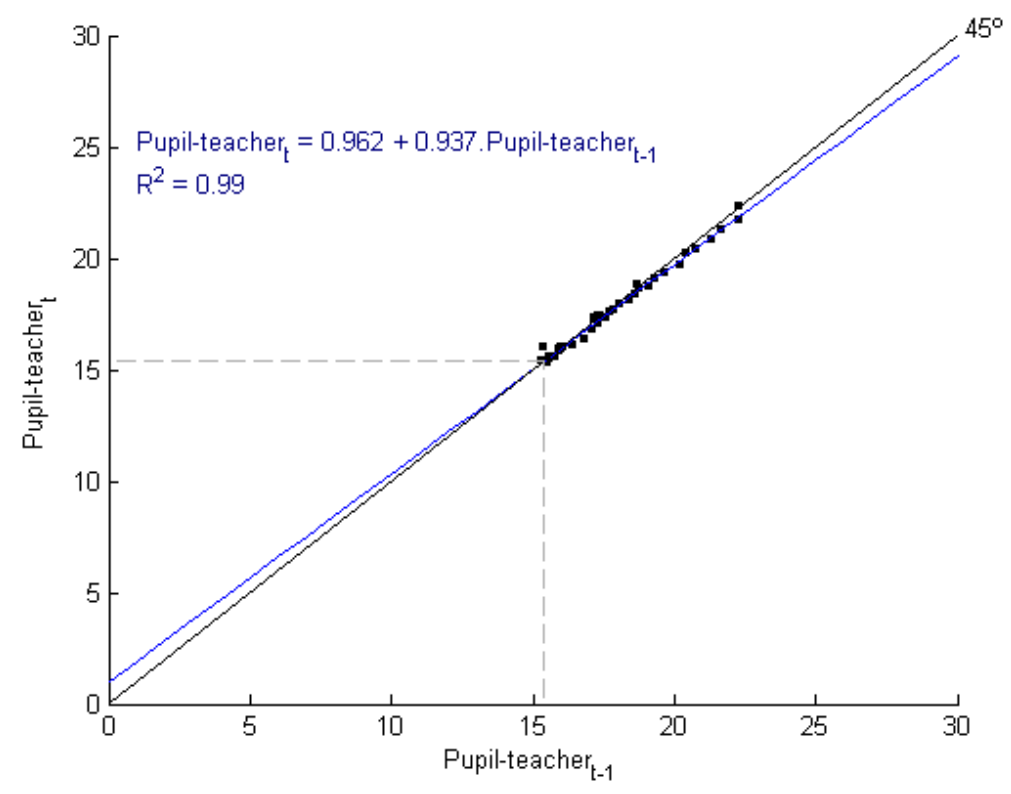

Figure 8 - Pupil-teacher ratio in US public elementary and secondary education, 1970-2010. The intersection between OLS estimation and the $45^{\circ}$ line gives the long run equilibrium of 15.36 .

GDP $^{3}$. The fraction $p$ is set to $26.43 \%$, which is equal to $2000-2010$ average of all staff compensation in primary and secondary public institutions as percentage of $\mathrm{GDP}^{4}$.

The human capital threshold structure proposed here does not have, to our knowledge, an empirical counterpart in the literature, which makes the calibration of $\bar{h}$ a real challenging task given all empirical issues that we have to deal with when measuring human capital externalities ${ }^{5}$. However, we still can define a reasonable value for $\bar{h}$ in order to be in accordance with

3 Available at White House website, table 2.3: < https://www.whitehouse.gov/omb/ budget/Historicals/>.

4 Available in World Bank Databank - Education Statistics. $p$ would be equal to $33.83 \%$ if we considered all educational levels and not only primary and secondary.

5 As an addition to the calibration, we could try to reach $\bar{h}$ using the threshold estimation method proposed by Hansen (2000). We leave this for future research. 
Acemoglu \& Angrist (2000) and Iranzo \& Peri (2009) evidences and, thus, a similar $\overline{h^{T}}$. Moreover, we can define a threshold that takes in account the human capital structure summed up by Caselli (2005) and also used in the index of human capital per worker given by PWT 8.0, which is discussed in Appendix A. Thus, we set $\overline{h^{T}}=2.56$, which is equivalent to an average of 8 years of schooling in the teachers group, for two reasons: $i$ ) 8 years of schooling is the threshold calculated by Psacharopoulos (1994) to define a discontinuity in the return of one more year of schooling on earnings, and ii) it is assumed to be a required minimum value ${ }^{6}$ that guarantee the average teacher would be sufficiently skilled (and the quality of provided education would be sufficiently high) to trigger the externality.

In order to reach the whole calibrated model we now need to define a value for the education quality return $v$ and the externality magnitude $\gamma$ (all calculations steps are at Appendix A). Given empirical issues on estimating returns to teacher quality while controlling for teacher quantity, there isn't a consensus in the literature about what would be a reasonable $v$, although, just as noted in Gilpin \& Kaganovich (2012), there are evidences that $v>0$. However, $\gamma$ can be inferred by the estimations of Iranzo \& Peri (2009): since external effects of an increase in the proportion of college graduates are around $3 \%-9 \%$ and, according to micro literature, return to one more year of schooling ${ }^{7}$ is around $6 \%-12 \%, \gamma$ is set to 0.38 .

\footnotetext{
$6 \quad$ An average of 8 years of schooling is equivalent to a completed primary education in all countries, since the biggest cycle duration of primary education in 2010 was 8 years in Ireland. Data available in: <http://www.epdc.org/level/primary/search?school_level= $81 \&$ indicators $=668 \&$ year_from $=2010 \& y e a r \_t o=2010>$.

7 A good survey of the estimates is in Psacharopoulos (1994).
} 
Table 1 - Calibrated parameters

\begin{tabular}{lccc}
\hline \hline Parameter & Value & Source \\
\hline & & 0.50 & - \\
Education quality return & $v$ & 0.62 & - \\
& & 1.71 & Micro literature \\
\hline Human capital externality magnitude & $\gamma$ & 0.38 & - \\
Upper bound of innate ability & $\bar{B}$ & 1 & Erosa, Koreshkova \& Restuccia (2010) \\
CRRA & $\sigma$ & 2 & - \\
Exogenous level of aggregate productivity & $A$ & 1 & Erosa, Koreshkova \& Restuccia (2010) \\
Human capital share in the production function & $\beta$ & 0.67 & NCES \\
Proportion of teachers in the population & $\theta$ & 0.0651 & White House \\
Income tax rate & $\tau_{M}$ & 0.0992 & World Bank \\
Proportion of govt. budget spent with teachers & $p_{t}$ & 0.2386 & Micro literature \\
Teacher's human capital threshold & $h^{T}$ & 2.56 & - \\
Constant & $\mathrm{C}$ & 6 & - \\
Constant & $\mathrm{D}$ & 6 & \\
\hline
\end{tabular}

Given this absence of a consensual $v$, we simulate our model with three possible values for this parameter in order to reach (when the externality is acting) decreasing, constant and increasing returns for education quality. We arbitrarily assumed a $v$ of $0.5^{8}(v+\gamma<1)$ in the first case and a $v$ of 0.62 in the second case $(v+\gamma=1)$. Berhman \& Birdsall (1983) estimations are used in order to reach $v$ that guarantee increasing returns: $v=1.71$.

We are able now to do some simulations and evaluate the policy effectiveness in this calibrated economy. First, two economies with distinct initial conditions are compared in the absence of any policy: since our teacher's human capital threshold is set to match the human capital level of an economy with an average of 8 years of schooling, we compare an economy with an initial average of 11 years of schooling, such as US in 1970, and an economy with half of this, such as Phillipines in 1970. Table 2 illustrates what would

8 This value is consistent with the evidence of education quality being as much important as education quantity if we had assumed an usual Cobb-Douglas human capital accumulation function with only these two inputs and coefficients totaling 1. 
Table 2 - Ratio of teacher's human capital

\begin{tabular}{c|cc}
\hline \hline & $\mathrm{t}=0$ & $\mathrm{t}=100$ \\
\hline$v+\gamma<1$ & 1.5785 & 34.3151 \\
$v+\gamma=1$ & 1.5785 & $\infty$ \\
$v+\gamma>1$ & 1.5785 &. \\
\hline \hline
\end{tabular}

Table 3 - Minimum policy changes to reach convergence

\begin{tabular}{cc|ccc}
\hline \hline & & Only $\Delta \tau>0$ & Only $\Delta p>0$ & Both $\Delta>0$ \\
\hline \multirow{2}{*}{$v+\gamma<1$} & $\Delta_{\min } \tau$ & $49.4 \%$ & $0.0 \%$ & $27.2 \%$ \\
& $\Delta_{\min } p$ & $0.0 \%$ & $26.5 \%$ & $10.2 \%$ \\
\hline \multirow{2}{*}{$v+\gamma=1$} & $\Delta_{\min } \tau$ & $65.5 \%$ & $0.0 \%$ & $34.3 \%$ \\
& $\Delta_{\min } p$ & $0.0 \%$ & $35.2 \%$ & $12.9 \%$ \\
\hline \hline
\end{tabular}

be the ratio (rich/poor) of teachers' human capital average when $t=0$ and 100 periods after that, for all $v$ values $^{9}$ : the case when $v+\gamma<1$ is the one presented in figure 6 where $\frac{\left(h_{s s}^{T}\right)^{\prime \prime}}{\left(h_{s s}^{T}\right)^{\prime}}=34.3151$.

Then, we calculate what would be the minimum positive change in policy parameters, i.e. $\left(\tau_{M}, \tau_{T}, p\right)$, which would make the poorer economy escape from the middle-income trap ${ }^{10}$. Table 3 summarizes the results of this exercise with $\tau_{M}=\tau_{T}=\tau$. Despite the different values, the intuition behind all of these results is the same: a considerable increase in the tax income rate and/or in the proportion of the government budget spent with teachers' salaries is required to let the poorer country overcome the middle-income trap.

9 A teacher's human capital ratio of 1.58 and 34.32 means a GDP per capita ratio of 1.36 and 10.67, respectively. When $v>1$, teacher's human capital of both countries converge to $\infty$ which means that the ratio is undefined.

10 There is no trap when $v>1$ and, thus, we only discuss intuitively the simulation results in this case. 
These minimum policy changes, however, are just the required ones to guarantee that, without externality, $h_{s s}^{T}>\overline{h^{T}}$. Figure 9 illustrates this exercise: the minimum policy changes are such that the low steady-state equilibrium moves from A to B and B is greater than human capital threshold $\overline{h^{T}}$. Thus, the poorer country may have to sustain these higher tax rates and higher spending with teachers' salaries for a prolonged period. This may imply an unsustainable burden for current generations since a higher tax rate means a lower level of consumption in $t$. Moreover, the cost of the required policy grows in magnitude and also in the number of periods that have to be sustained when $v$ and $\gamma$ grows. Therefore, for sufficiently high values of these two parameters, even the minimum policy changes would be unfeasible. In summary, the required policy to overcome the middle-income trap has a considerable cost in all cases. 


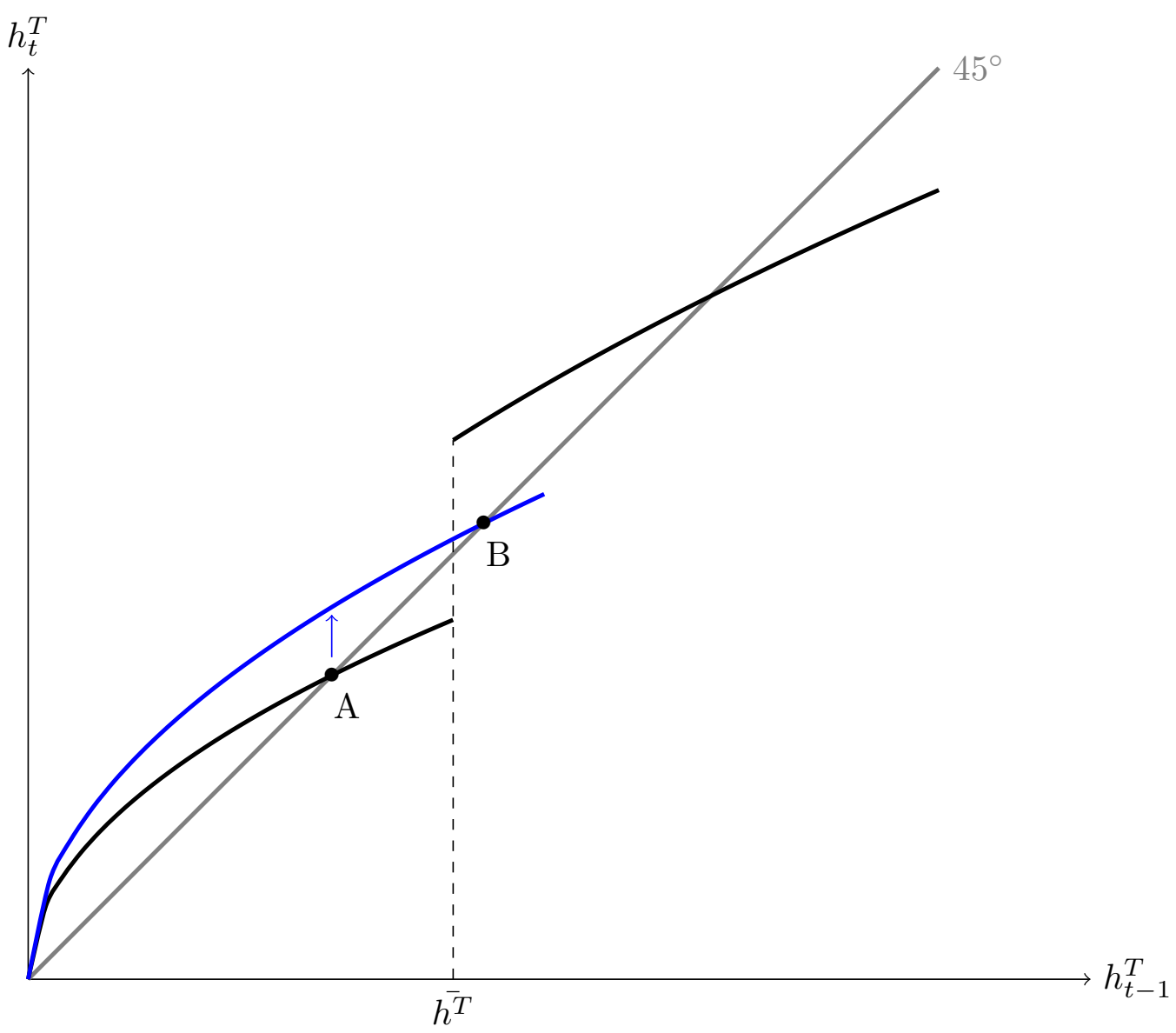

Figure 9 - Simulation exercise of required minimum policy changes. 



\section{Concluding Remarks}

This paper assesses the role of education quality in the non-convergence phenomenon of GDP per capita. By making education quality equal to the average of teachers' human capital, just as in Gilpin \& Kaganovich (2012), the paper analyzes how the quality (and not only quantity) of human capital contributes to GDP variability in response to model parameters.

It is shown that differences in education quality by itself can generate multiple-steady states or different endogenous growth paths. This paper reaches this result by making education quality endogenous and not only a calibrated parameter or a policy variable as in Tamura (2001), for example. This paper also shows that, even when education quality return is decreasing, multiple steady-states environment arises if human capital externalities are acting. Therefore, initial distribution of human capital is of great importance in forecasting what will be a country's long-run equilibrium.

Some simulation exercises are done in order to gain some insights about what would be the required public policy if a poor country is aiming convergence. Using USA parameters to build a benchmark economy, it is shown that the required minimum changes in income tax rate and in the proportion of government budget spent with teachers' salaries are big in magnitude in all specifications. The cost to current generations of this required policy grows with the importance of education quality in the human capital accumulation function, and could be unsustainable if this importance is sufficiently high. 



\section{Referências}

ACEMOGLU, D. A microfoundation for social increasing returns in human capital accumulation. The Quarterly Journal of Economics, Vol. 111, n. No. 3, p. pp. 779-804, August 1996. 35

ACEMOGLU, D.; ANGRIST, J. How large are the social returns to education? evidence from compulsory schooling laws. In: BERNANKE, B.; ROGOFF, K. (Ed.). NBER Macroeconomic Annual. [S.l.: s.n.], 2000. p. 9-59. $19,35,51$

AIYAR, S. et al. Growth Slowdowns and the Middle-Income Trap. [S.l.], 2013. Disponível em: < https://www.imf.org/external/pubs/ft/wp/2013/wp1371. pdf $>.37$

AZARIADIS, C.; DRAZEN, A. Threshold externalities in economic development. The Quarterly Journal of Economics, Vol. 105, n. No. 2, p. pp. 501-526, May 1990. 21, 35

BERHMAN, J. R.; BIRDSALL, N. The quality of schooling: Quantity alone is misleading. The American Economic Review, Vol. 73, n. No. 5, p. pp. 928-946, December 1983. 52, 64, 65

CASELLI, F. Accounting for cross-country income differences. In: AGHION, P.; DURLAUF, S. N. (Ed.). Handbook of Economic Growth. [S.l.]: Elsevier, 2005. Vol. 1A, cap. 9, p. pp. 680-738. 51, 64

EICHENGREEN, B.; PARK, D.; SHIN, K. Growth Slowdowns Redux: New Evidence on the Middle-Income Trap. [S.l.], 2013. Disponível em: $<$ http://www.nber.org/papers/w18673>. 37

EROSA, A.; KORESHKOVA, T.; RESTUCCIA, D. How important is human capital? a quantitative assessment of world income inequality. The Review of Economic Studies, Vol. 77, n. No. 4, p. pp. 1421-1449, October 2010. 49, 52

GALOR, O.; MOAV, O. Ability-biased technological transition, wage inequality, and economic growth. The Quarterly Journal of Economics, Vol. 115, n. No. 2, p. pp. 469-497, May 2000. 23

GALOR, O.; MOAV, O. From physical to human capital accumulation: Inequality and the process of development. The Review of Economic Studies, Vol. 71, n. No. 4, p. pp. 1001-1026, October 2004. 21 
GALOR, O.; ZEIRA, J. Income distribution and macroeconomics. The Review of Economic Studies, Vol. 60, n. No. 1, p. pp. 35-52, January 1993. 21

GILPIN, G.; KAGANOVICH, M. The quantity and quality of teachers: Dynamics of the trade-off. Journal of Public Economics, Vol. 96, n. No. 4, p. pp. 417-429, April 2012. 19, 24, 45, 51, 57

HALL, R. E.; JONES, C. I. Why do some countries produce so much more output per worker than others? The Quarterly Journal of Economics, Vol. 144, n. No. 1, p. pp. 83-116, February 1999. 64

HANSEN, B. E. Sample splitting and threshold estimation. Econometrica, Vol. 68, n. No. 3, p. pp. 575-603, May 2000. 50

HANUSHEK, E. A. Economic growth in developing countries: The role of human capital. Economics of Education Review, Vol. 37, p. pp. 204-212, December 2013. 17

HANUSHEK, E. A.; WOESSMANN, L. Schooling, educational achievement, and the latin american growth puzzle. Journal of Development Economics, Vol. 99, n. No. 2, p. pp. 497-512, November 2012. 17

IRANZO, S.; PERI, G. Schooling externalities, technology, and productivity: Theory and evidence from u.s. states. The Review of Economics and Statistics, Vol. 91, n. No. 2, p. pp. 420-431, May 2009. 19, 35, 51, 63

NAGLER, M.; PIOPIUNIK, M.; WEST, M. R. Weak Markets, Strong Teachers: Recession at Career Start and Teacher Effectiveness. [S.l.], 2015. Disponível em: <http://www.nber.org/papers/w21393>. 44

PSACHAROPOULOS, G. Returns to investment in education: a global update. World Development, v. 22, n. 9, p. 1325-1343, September 1994. 51, 64

SCHOELLMAN, T. Education quality and development accounting. The Review of Economic Studies, Vol. 79, n. No. 1, p. pp. 388-417, January 2012. 17

TAMURA, R. Teachers, growth, and convergence. Journal of Political Economy, Vol. 109, n. No. 5, p. pp. 1021-1059, October 2001. 17, 57 


\section{Apêndice A}

\section{- How to reach equations (2.6) and (2.7)}

Equations (2.6) and (2.7) are the result of integrating $h_{t}^{i}$, equations (2.3), (2.4), and (2.5), which represents, respectively, individual ability threshold, perfectly competitive markets and government's budget constraint.

Thus,

$$
\begin{aligned}
& H_{t}=\int_{0}^{a_{t}^{\star}-\bar{B} \cdot \theta} h_{t}^{i}\left(a_{t}^{i}\right) \cdot d F\left(a_{t}^{i}\right)+\int_{a_{t}^{\star}}^{\bar{B}} h_{t}^{i}\left(a_{t}^{i}\right) \cdot d F\left(a_{t}^{i}\right) \\
& =\int_{0}^{a_{t}^{\star}-\bar{B} \cdot \theta} \cdot C_{t} \cdot a_{t}^{i} \cdot\left(h_{t-1}^{T}\right)^{v} \cdot f\left(a_{t}^{i}\right) \cdot d a_{t}^{i}+\int_{a_{t}^{\star}}^{\bar{B}} \cdot C_{t} \cdot a_{t}^{i} \cdot\left(h_{t-1}^{T}\right)^{v} \cdot f\left(a_{t}^{i}\right) \cdot d a_{t}^{i} \\
& =C_{t} \cdot\left(h_{t-1}^{T}\right)^{v} \cdot\left(\int_{0}^{a_{t}^{\star}-\bar{B} \cdot \theta} a_{t}^{i} \cdot \frac{1}{\bar{B}} \cdot d a_{t}^{i}+\int_{a_{t}^{\star}}^{\bar{B}} a_{t}^{i} \cdot \frac{1}{\bar{B}} \cdot d a_{t}^{i}\right) \\
& =\frac{C_{t} \cdot\left(h_{t-1}^{T}\right)^{v}}{\bar{B}} \cdot\left(\left[\frac{\left(a_{t}^{i}\right)^{2}}{2}\right]_{0}^{a_{t}^{\star}-\bar{B} \cdot \theta}+\left[\frac{\left(a_{t}^{i}\right)^{2}}{2}\right]_{a_{t}^{\star}}^{\bar{B}}\right) \\
& =\frac{C_{t} \cdot\left(h_{t-1}^{T}\right)^{v}}{2 \cdot \bar{B}} \cdot\left(\left(a_{t}^{\star}\right)^{2}-2 \cdot a_{t}^{\star} \cdot \bar{B} \cdot \theta+\bar{B}^{2} \cdot \theta^{2}+\bar{B}^{2}-\left(a_{t}^{\star}\right)^{2}\right) \\
& =\frac{C_{t} \cdot \bar{B} \cdot\left(1+\theta^{2}\right)}{2} \cdot\left(h_{t-1}^{T}\right)^{v}-C_{t} \cdot\left(h_{t-1}^{T}\right)^{v} \cdot \theta \cdot a_{t}^{\star} \\
& =\frac{C_{t} \cdot \bar{B} \cdot\left(1+\theta^{2}\right)}{2} \cdot\left(h_{t-1}^{T}\right)^{v}-C_{t} \cdot\left(h_{t-1}^{T}\right)^{v} \cdot \theta \cdot \frac{\left(1-\tau_{T}\right) \cdot w_{t}^{T}}{\left(1-\tau_{M}\right) \cdot w_{t}^{M}} \cdot \frac{1}{C_{t} \cdot\left(h_{t-1}^{T}\right)^{v}} \\
& =\frac{C_{t} \cdot \bar{B} \cdot\left(1+\theta^{2}\right)}{2} \cdot\left(h_{t-1}^{T}\right)^{v}-\theta \cdot \frac{\left(1-\tau_{T}\right) \cdot \frac{p \cdot \tau_{M} \cdot w_{t}^{M} \cdot H_{t}}{\theta \cdot\left(1-p \cdot \tau_{T}\right)}}{\left(1-\tau_{M}\right) \cdot w_{t}^{M}} \\
& =\frac{C_{t} \cdot \bar{B} \cdot\left(1+\theta^{2}\right)}{2} \cdot\left(h_{t-1}^{T}\right)^{v}-\theta \cdot \frac{\left(1-\tau_{T}\right) \cdot p \cdot \tau_{M} \cdot w_{t}^{M} \cdot H_{t}}{\left(1-\tau_{M}\right) \cdot w_{t}^{M} \cdot \theta \cdot\left(1-p \cdot \tau_{T}\right)} \\
& =\frac{C_{t} \cdot \bar{B} \cdot\left(1+\theta^{2}\right)}{2} \cdot\left(h_{t-1}^{T}\right)^{v}-\frac{p \cdot\left(1-\tau_{T}\right)}{\left(1-p \cdot \tau_{T}\right)} \cdot \frac{\tau_{M}}{\left(1-\tau_{M}\right)} \cdot H_{t}
\end{aligned}
$$

and finally 


$$
H_{t}=\frac{C_{t} \cdot \bar{B}}{2} \cdot\left[\frac{\left(1+\theta^{2}\right) \cdot\left(1-p \cdot \tau_{T}\right) \cdot\left(1-\tau_{M}\right)}{\left(1-p \cdot \tau_{T}-\tau_{M} \cdot(1-p)\right)}\right] \cdot\left(h_{t-1}^{T}\right)^{v}
$$

Equation (2.7) just come from equation (2.6) and the fact that $H_{t}+$ $\theta \cdot h_{t}^{T}=\int_{0}^{\bar{B}} h_{t}^{i}\left(a_{t}^{i}\right) \cdot d F\left(a_{t}^{i}\right)=\frac{C_{t} \cdot\left(h_{t-1}^{T}\right)^{v} \cdot \bar{B}}{2}$.

\section{- Rewritting $h_{0}^{T}$ as a function of initial conditions}

Since we assumed that $h_{0}^{i}$ is distributed uniformly over the interval $[x-\lambda ; x+\lambda], h_{0}^{T}$ and $H_{0}$ could be calculated directly, noting only that individual ability threshold that defines career choice can be restated as individual human capital threshold.

$$
\begin{aligned}
h_{0}^{T} & =\theta^{-1} \cdot \int_{h_{0}^{\star}-2 \cdot \lambda \cdot \theta}^{h_{0}^{\star}} h_{0}^{i} \cdot d F\left(h_{0}^{i}\right) \\
& =\theta^{-1} \cdot \int_{h_{0}^{\star}-2 \cdot \lambda \cdot \theta}^{h_{0}^{\star}} h_{0}^{i} \cdot f\left(h_{0}^{i}\right) \cdot d h_{0}^{i} \\
& =\theta^{-1} \cdot \int_{h_{0}^{\star}-2 \cdot \lambda \cdot \theta}^{h_{0}^{\star}} h_{0}^{i} \cdot \frac{1}{2 \cdot \lambda} \cdot d h_{0}^{i} \\
& =\frac{1}{2 \cdot \lambda \cdot \theta} \cdot\left[\frac{\left(h_{0}^{i}\right)^{2}}{2}\right]_{h_{0}^{\star}-2 \cdot \lambda \cdot \theta}^{h_{0}^{\star}} \\
& =\frac{1}{4 \cdot \lambda \cdot \theta} \cdot\left[\left(h_{0}^{i}\right)^{2}-\left(h_{0}^{i}\right)^{2}+4 \cdot \lambda \cdot \theta \cdot h_{0}^{\star}-4 \cdot \lambda^{2} \cdot \theta^{2}\right] \\
h_{0}^{T} & =h_{0}^{\star}-\theta \cdot \lambda
\end{aligned}
$$

It is straightforward to show that

$$
H_{0}=-\theta \cdot h_{0}^{\star}+\theta^{2} \cdot \lambda+x
$$


Now, recall equations (2.3) and (2.5), the assumption of $\theta$ teachers $\forall t$, and note that at $t=0$ we have:

$$
\begin{aligned}
h_{0}^{\star} & =\frac{\left(1-\tau_{T}\right) \cdot w_{0}^{T}}{\left(1-\tau_{M}\right) \cdot w_{0}^{M}} \\
& =\frac{\left(1-\tau_{T}\right)}{\left(1-\tau_{M}\right) \cdot w_{0}^{M} \cdot \frac{p \cdot \tau_{M} \cdot w_{0}^{M} \cdot H_{0}}{\theta \cdot\left(1-p \cdot \tau_{T}\right)}} \\
& =\frac{\left(1-\tau_{T}\right)}{\left(1-\tau_{M}\right)} \cdot \frac{p \cdot \tau_{M} \cdot H_{0}}{\theta \cdot\left(1-p \cdot \tau_{T}\right)} \\
h_{0}^{\star} & =\frac{\left(1-\tau_{T}\right)}{\left(1-\tau_{M}\right)} \cdot \frac{p \cdot \tau_{M}}{\theta \cdot\left(1-p \cdot \tau_{T}\right)} \cdot\left[-\theta \cdot h_{0}^{\star}+\theta^{2} \cdot \lambda+x\right] \\
h_{0}^{\star} & =\frac{\left(1-\tau_{T}\right) \cdot p \cdot \tau_{M}}{\theta \cdot\left(1-p \cdot \tau_{T}-\tau_{M} \cdot(1-p)\right)} \cdot\left[\theta^{2} \cdot \lambda+x\right]
\end{aligned}
$$

Finally, replacing this $h_{0}^{\star}$ function on $h_{0}^{T}$

$$
\begin{aligned}
h_{0}^{T} & =\frac{\left(1-\tau_{T}\right) \cdot p \cdot \tau_{M}}{\theta \cdot\left(1-p \cdot \tau_{T}-\tau_{M} \cdot(1-p)\right)} \cdot\left[\theta^{2} \cdot \lambda+x\right]-\theta \cdot \lambda \\
h_{0}^{T} & =\frac{\left(1-\tau_{T}\right) \cdot p}{\left(1-p \cdot \tau_{T}-\tau_{M} \cdot(1-p)\right)} \cdot \frac{\tau_{M} \cdot x}{\theta}-\left(1-\tau_{M}\right) \cdot \theta \cdot \lambda \cdot \frac{\left(1-p \cdot \tau_{T}\right)}{\left(1-p \cdot \tau_{T}-\tau_{M} \cdot(1-p)\right)}
\end{aligned}
$$

\section{- Reaching calibrated $\gamma$}

We can reach the calibrated value of $\gamma$ by targeting the return to education when the externality of Iranzo \& Peri (2009) is acting, and if the individual years of schooling were added in the human capital production function. Given the intervals of externality magnitude and returns to schooling (cited previously in the text), we can thus set a lower bound and upper bound to $\gamma$.

1. Lower bound: $\frac{0.06}{1-\underline{\gamma}}=0.06+0.03 \Longrightarrow \underline{\gamma} \approx 0.33$ 
2. Upper bound: $\frac{0.12}{1-\bar{\gamma}}=0.12+0.09 \Longrightarrow \bar{\gamma} \approx 0.43$

Thus, our calibrated $\gamma$ is set to equal the middle point between these bounds, i.e., 0.38 .

- Reaching calibrated $v$ using Berhman \& Birdsall (1983) estimations and Hall \& Jones (1999) definition of human capital

The estimations of education quality's return ranges from $2 \%$ to $28.6 \%$ in table 2 of Berhman \& Birdsall (1983). We use the mean value of $15.3 \%$ to reach $v$.

Individual income in our model is given by $y_{t}^{i}=\left(1-\tau_{M}\right) \cdot w_{t}^{M} \cdot h_{t}^{i}$, which implies along with equations (2.4), (2.6) and individual human capital production function:

$$
\begin{aligned}
\ln \left(y_{t}^{i}\right) & =\ln \left(1-\tau_{M}\right)+\ln \left(w_{t}^{M}\right)+\ln \left(h_{t}^{i}\right) \\
& =\ln \left(1-\tau_{M}\right)+\ln \left(w_{t}^{M}\right)+\ln (C)+\ln \left(a_{t}^{i}\right)+v \cdot \ln \left(h_{t-1}^{T}\right) \\
& =\text { constant }+\ln \left(w_{t}^{M}\right)+v \cdot \ln \left(h_{t-1}^{T}\right) \\
& =\text { constant }+\ln \left(A_{t}\right)+\ln (\beta)+(\beta-1) \cdot \ln \left(H_{t}\right)+v \cdot \ln \left(h_{t-1}^{T}\right) \\
& =\text { constant }+(\beta-1) \cdot \ln \left(\frac{C \cdot \bar{B}}{2} \cdot M_{t}\right)+(\beta-1) \cdot v \cdot \ln \left(h_{t-1}^{T}\right)+v \cdot \ln \left(h_{t-1}^{T}\right) \\
& =\text { constant }+\beta \cdot v \cdot \ln \left(h_{t-1}^{T}\right)
\end{aligned}
$$

Following Hall \& Jones (1999) and Psacharopoulos (1994), just as in Penn World Table 8.0 and summed up by Caselli (2005), the index of human capital per worker is defined as 
$h=e^{f(s)} \quad$ such that $\begin{cases}f(s)=0.134 \times s, & \text { if } s<4 \\ f(s)=0.134 \times 4+0.101 \times(s-4), & \text { if } 4 \leq s<8 \\ f(s)=0.134 \times 4+0.101 \times 4+0.068 \times(s-8), & \text { if } s \geq 8\end{cases}$

Since in 1970, year of the Census data used in Berhman \& Birdsall (1983), Brazil had an average years of schooling of less than $4, \ln \left(y_{t}^{i}\right)$ can be restated as

$$
\begin{aligned}
& \ln \left(y_{t}^{i}\right)=\text { constant }+\beta \cdot v \cdot \ln \left(e^{0.134 \times s_{t-1}^{T}}\right) \\
& \ln \left(y_{t}^{i}\right)=\text { constant }+\beta v(0.134) s_{t-1}^{T}
\end{aligned}
$$

However, following Berhman \& Birdsall (1983) estimations, the coefficient $(\beta v(0.134))$ is set to equal 0.153. Thus, using our $\beta$ of two thirds, we can define a value for $v$.

$$
\frac{2}{3} v(0.134)=0.153 \Longrightarrow v=\frac{0.153 \times 3}{0.134 \times 2} \Longrightarrow v \approx 1.71
$$

